Polymer-Supported

Asymmetric Catalysis: Resin-Bound Hydroxyprolylthreonine Derivatives in Enamine-Mediated Reactions

Synthesis

Angew. Chem. Int. Ed. 2008, 47, 6407-6410.

\title{
Resin-Bound Pyrrolidine Catalysts for Enamine-Mediated Reactions
}

Key words

organocatalysis

pyrrolidine catalyst

asymmetric

catalysis

enamine-mediated reaction

t-BuO<smiles>CCCOC(C)[C@H](NC(=O)C1CCCN1)C(=O)Nc1ccccc1</smiles><smiles>CCOC(C)C(NC(=O)C1CC(OC(C)(C)C)CN1)C(=O)Nc1ccccc1</smiles>

2<smiles>[H][R]1ccc(O)c(C(C)=O)[15cH]1</smiles><smiles>[X]C1CCC(=O)C1</smiles>
$\underset{\begin{array}{c}\text { MeOH, r.t., } 1 \mathrm{~h}, \text { then } \\ \text { microwave irradiation }\end{array}}{\stackrel{1 \text { or } 2(1 \mathrm{~mol} \%)}{110^{\circ} \mathrm{C}, 11 \text { min }}}$ 3 a: $R^{1}=5-F, n=2$

b: $\mathrm{R}^{1}=4-\mathrm{OEt}, \mathrm{n}=1$

c: $R^{1}=4-O M e, n=2$

d: $R^{1}=4-F, n=2$

e: $R^{1}=6-O M e, n=1$

f: $R^{1}=5-E t, n=1$

4 (2 equiv)

$110^{\circ} \mathrm{C}, 11 \mathrm{~min}$

3<smiles>[X]C1CCCC(=O)C1[R]</smiles>

6 (2 equiv)

g: $R^{1}=4-O E t, R^{2}=M e, X=C$

h: $R^{1}=5-C l, R^{2}=H, X=N A C$

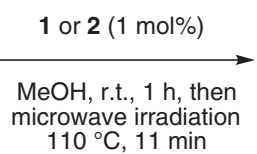

$110^{\circ} \mathrm{C}, 11 \mathrm{~min}$

Significance: Tentagel-bound asymmetric pyrrolidine catalysts $\mathbf{1}$ and $\mathbf{2}$ are reported for the preparation of optically active chromanones $\mathbf{5}$. The catalysts mediated the asymmetric tandem aldolMichael reactions with high enantioselectivity and complete diastereoselectivity. Thus, the reaction of $\mathbf{3}$ and cycloalkanones (4 and $\mathbf{6}$ ) was carried out with $\mathbf{1}$ in $\mathrm{MeOH}$. The reaction mixture was then heated under microwave irradiation to give $\mathbf{5 a}-\mathbf{h}$ in $71-90 \%$ yield with up to $97 \%$ ee (8 examples). The reaction with $\mathbf{2}$ under similar conditions afforded ent-5b-g and $\mathbf{5 h}$ in 77-94\% yield with up to $99 \%$ ee (7 examples).
Comment: The polymeric catalysts were also effective for kinetic resolution of racemic 3-methylcycloalkanones $\mathbf{4}$ with $\mathbf{3}$ (2 equiv) to give the unreacted 3-methylcycloalkanone in 35-43\% yield with 95-99\% ee. Enantioselective aldol, Michael, and Robinson annulations, as well as Mannich reactions with catalysts $\mathbf{1}$ and $\mathbf{2}$ are also described.

SYNFACTS Contributors: Yasuhiro Uozumi, Yoichi M. A. Yamada, Hidetoshi Ohta

Dol: 10.1055/s-0028-1083396; Reg-No.: Y11208SF 